Mg. theol.

\title{
DIĀNA HRISTENKO
}

\section{EVANָĢELLISKI LUTERISKĀS BAZNİCAS SOVETIZĀCIJA - LATVIJAS UN IGAUNIJAS PIEMĒRS (1946-1949)}

Šĩ raksta mērķis ir atklāt Latvijas un Igaunijas evangêélisko baznīcu pārveidošanas galvenos aspektus un to pielāgošanos sovetizācijai no 1946. gada līdz 1949. gadam, raksturot to, kādā veidā un kāpēc šīs izmaiņas jauno arhibīskapu vadībā bija tik būtiskas, ka Latvijas Evangêêliski luterisko baznīcu (LELB) un Igaunijas Evaņgêeliski luterisko baznīcu (Eesti Evangeelne Luterlik Kirik - EELK) varētu dēvēt par padomju evaņgéliski luteriskajām baznīcām, kas principiāli atšḳīās no organizācijām pirms Otrā pasaules kara. Šie procesi Latvijā un Igaunijā nenotika identiski, drīzāk ar pāris mēnešu, dažreiz pat gadu nobīdi, tomēr ir tik līdzīgi, ka, analizējot pārmaiņas LELB un EELK, iespējams saskatīt gan vienādu politiku no padomju reliǵijas politikas puses, gan līdzīgu reakciju uz šo politiku no luterāņu puses un ticīgās sabiedrības kopumā. Viena no galvenajām atziṇām, kura gūta, strādājot ar arhīva materiāliem ${ }^{1}$ un līdzšinējo literatūru, ${ }^{2}$ ka Latvijas Ev.-lut. baznīca un garīdzniecība sovetizāciju ir piedzīvojusi pirmā, savukārt Igaunijas baznīcas sovetizācija ir notikusi, jau mācoties no procesiem, kuri ir risinājušies Latvijā. Latvijas

1 Latvijas Valsts arhīvs, 1448. f., 1. apr., 41. I., 19. Ip.; Eesti Rahvusarhiiv, R-1989 f., 2. apr., 7. l., atskaites par 1947.-1948. gadu.

2 Robert F. Goeckel, Soviet Religious policy in Estonia and Latvia. Playing harmony in the singing revolution (Indiana University press: 2018), 26-27; Internal Church Structure. The Use of Terror against the Church; Juko Talonens, Baznīca staļinisma žñaugos. Latvijas evangéēliski luteriskā baznīca no 1944-1950. gadam (Rīga: Luterisma mantojuma fonds, 2009), 151-152. 
Ev.-lut. baznīca un Igaunijas Ev.-lut. baznīca pēc Otrā pasaules kara bija līdzīgas, taču ne vienādas organizācijas, tāpēc, protams, ir atšksirības sovetizācijā, kuras ir izraisījuši cilvēku faktori (padomju amatpersonu personības īpašības un darbības veiksmīgums), ticīgo skaits (Latvijā sabiedrība bija daudz mazāk sekularizēta, Igaunijā dominēja luterāṇi), fiziskā geogrāfija (Igaunijai ir salas, Latvijai nav) u.c. jautājumi. Šī "Latvijas pilotprojekta" tendence tomēr atklājās vairākos sovetizācijas aspektos. Vispārējā Padomju Savienības politika mācīties no iepriekš realizētiem "okupācijas projektiem"3 šo domu pastiprina vēl vairāk.

Latvijas un Igaunijas Ev.-lut. baznīcu vēsture ir neapšaubāmi jāskata abu valstu vēstures kontekstā, citādi baznīcas procesi un ietekme uz sabiedrību nav saprotami. Analizējot sovetizāciju no 1946. gada līdz 1949. gadam, kad Latvija un Igaunija atradās citas valsts sastāvā, ir nepieciešams atkāpties un atskatīties uz vēstures notikumiem, kas notika īsi pirms okupācijas, kura ilga gandrīz 50 gadus. Latvija un Igaunija Otrajā pasaules karā tika okupētas trīskārt, pirmo reizi to izdarīja Padomju Savienība 1940. gadā saskaņā ar Molotova-Ribentropa pakta slepenajiem papildprotokoliem un ietekmes sfēru sadalījumu, pēc tam nacistiskā Vācija 1941. gadā, kad tā sāka karot ar savu iepriekšējo sabiedroto PSRS, un kara izskaņā un nacistiskās Vācijas kara zaudējuma agonijā PSRS atguva savas ietekmes sfēras 1944.-1945. gadā. Pēdējā okupācija izmainīja Baltijas valstu vēsturi, sabiedrību, dzīvesveidu un apziņu, tiekot pakḷautai sovetizācijai visās dzīves jomās. Ar sovetizēšanu saprotot jebkuras sabiedrības un valsts ieklaušanu padomju sistēmā likumīgi un pēc būtības, LELB un EELK bija lielu pārmaiñu priekšā.

Viens no raksta mērķiem ir salīdzināt luterāņu baznīcu sovetizāciju no viena skatpunkta, veltot uzmanību līdzīgajam un atšksirīgajam pārmaiņu procesā. Līdz šim rakstītā historiogrāfija lielākoties bija ierobežota telpā un valodā - monogrāfijas ${ }^{4}$ un raksti latviešu valodā par LELB, promocijas darbi ${ }^{5}$ un raksti ang̨̧ u un igauņu valodā ${ }^{6}$ par EELK. ${ }^{7}$

3 Piemēram, Baltijas okupācija tika īstenota pēc pielāgotas Baltkrievijas un Ukrainas okupācijas politikas un pañēmieniem, savukārt par vispārēju baznīcas sovetizācijas "pilotprojektu" var uzskatīt Krievijas pareizticīgo baznīcu, kas padomju reliǵijas kontroli izdzīvoja jau 20. gs. 30. gados un Otrā pasaules kara laikā.

4 Juko Talonens, Baznīca stal̦inisma žnaugos. Latvijas Evang̣éliski luteriskā baznīca padomju okupācijas laikā no 1944. lìdz 1950. gadam (Rīga: Luterisma mantojuma fonds, 2009); L. Rozentāls, Izdzìvošana. Sinodālais pārvaldes princips Latvijas Evanǵgéliski luteriskajā baznīcā 1948.-1984. gadā (Rīga: LU Akadēmiskais apgāds, 2017).

5 Riho Altnurme, Eesti Evangeeliumi Luteriusu Kirik ja Nõukogude riik 1944-1949 (Igaunijas Evangóēliski luteriskā baznīca un padomju valsts 1944.-1949) (Tartu Universitāte, Teologijas fakultāte, 2000).

6 Piemēram, Riho Altnurme, Atko-Sulhan Remmel, "History of Estonian Ecumenism", in Church Life During Occupations, 109-125 (Tartu, Tallinn: Estonian Council of Churches, 2009).

7 Riho Altnurme, "Theology and technology - new possibilities for the study of church history", in LU 78. konferences teoloǵijas un reliǵijpētniecības sekcija, 1. daḷa. 17.02.2020. 
Atsevišķ uzmanību jaunajam LELB arhibīskapam iepriekš pievērsusi gan raksta autore, ${ }^{8}$ gan V. Tēraudkalns, ${ }^{9}$ izcelı ot padomju periodu ar Gustavu Tūru kā atsevišḳi pētāmu laiku LELB vēsturē. Vispārīga informācija anglı u valodā pieejama Roberta Gekela ${ }^{10}$ un Sabīnas Rametas $^{11}$ apjomīgajos darbos, taču tie ir veltīti reliǵijai PSRS kopumā, aptverot arī daudz lielāku laika posmu līdz pat PSRS sabrukumam. Valodu prasmēm vai to trūkumam un nozīmīgumam Baltijas baznīcu vēstures pētniecībā uzmanību pievērsis Tartu Universitātes profesors Riho Altnurme, iezīmējot visiem zināmo situāciju humanitāro zinātņu laukā - Baltijas valstu humanitāro zinātņu studenti un pētnieki bieži vien prot pat vairāk nekā trīs dzīvās valodas - savu dzimto, angḷu, vācu, krievu valodu u. c., taču reti kad tās ir pārējo Baltijas valstu valodas, - latvieši neprot igauņu valodu, igauņi lietuviešu utt. Protams, ir izņēmumi, taču šo valodas prasmju neesamība ietekmē pētnieku darbu un pieejamību avotiem, domu un vēstures pētniecības pañēmienu apmaingu utt. ${ }^{12}$ Jau šobrīd eksistē mašīntulkošana un dažādi tulkošanas rīki, taču, kamēr šie rīki nav tikuši lìdzi cilvēka prātam un teoloǵijai ${ }^{13}$, problēma pastāv un ietekmē pētniecības kvalitāti un nozīmīgumu. Mazu valstu pētniekiem nemeklēt, nestrādāt un nedomāt transnacionālās vēstures kategorijā nozīmē norobežoties no cilvēkiem ar līdzīgu pieredzi un avotiem.

Autore uzskata, ka luterāņu baznīcu vēsture padomju periodā ir jāpēta, izmantojot transnacionālās vēstures pieeju. Tās nodalot atsevišķi, netiek sniegts skatijums uz baznīcās notiekošo. Šādu transnacionālās vēstures pieeju un historiogrāfijas problemātiku tieši Baltijas baznīcu vēsturē atkal ir akcentējis Riho Altnurme, norādot, ka baznīcas vēstures pētniecībā ir izteikta nacionālās vēstures dominance, nepētot kustības un procesus, kas šķērso tālaika un mūsdienu valstu robežas. ${ }^{14}$ Lìdzīgu problemātiku par Baltijas reğiona vēstures pētniecību, tiesa, par citu notikumu - Pirmo pasaules karu Baltijā un Latvijā un jaunāko laiku pētniecību kopumā - saskata vēsturnieks Ėriks Jēkabsons ${ }^{15}$.

8 Diāna Grīnvalde, "Religiskais konformisms LPSR: LELB attiecības ar padomju varu, 19461954" // HOMO ET. Persona. Societas. Natura. Innovationes (Rīga: LU Akadēmiskais apgāds, 2020), 51-61.

9 Valdis Tēraudkalns, "Cerību laiks: LELB kontakti ar Anglijas baznīcu arhibīskapa Gustava Tūra darbības laikā (1946-1968)”, Cel̦š 71 (2020): 103-135.

10 Robert F. Goeckel, Soviet Religious Policy in Estonia and Latvia. Playing Harmony in the Singing Revolution (Bloomington: Indiana University Press, 2018).

11 Sabrina P. Ramet (Ed), Religious Policy in The Soviet Union (Cambridge: Cambdrige University Press, 1994).

12 Riho Altnurme, "Theology and technology - new possibilities for the study of church history", in LU 78. konferences teoloǵijas un reliǵijpētniecības sekcija, 1. daḷa, 17.02.2020.

13 Ibid.

14 Ibid.

15 Pirmā pasaules kara galvenās problēmas: izpētes stāvoklis Latvijā // Latvijas Kara muzeja gadagrāmata. XV (Rīga: Kara muzejs, 2014), 17-19. 
Luterāņu draudzes Lietuvā šajā padomju periodā vēl jāpēta, tad PSRS religíijas politika pret Baltijas luterāņiem, tai skaitā latviešu luterāņu draudzēm Lietuvā, būtu analizēta aptveroši.

Pētijumā izmantoti gan Latvijas arhīvu fondi' ${ }^{16}$, gan Igaunijas Nacionālā arhīva Tallinas ${ }^{17}$ un Tartu ${ }^{18}$ nodaļās atrodamā informācija. Ziņas par EELK Virsvaldē notiekošo un attiecībām ar padomju varu sniedza EELK konsistorijas arhīvs Tallinā. ${ }^{19}$ Izmantota arī latviešu padomju un trimdas prese, igauņu prese, kuras kā laikmeta piemēri ilustrē latviešu un igauņu luterāņu reliǵisko dzīvi laikā no 1946. gada līdz 1949. gadam, arī vēlākas publikācijas.

Abu baznīcu sovetizāciju raksta hronologiskajās robežās vislabāk var analizēt no šādiem aspektiem - padomju amatpersonu darbība Latvijā un Igaunijā, baznīcu satversmju izmaiñas un jaunās baznīcas amatpersonas, padomju varas un ev.-lut. baznīcu arhibīskapu savstarpējā mijiedarbība.

Padomju kontroles darbībā instrumenti baznīcas

Laika posms no 1944. līdz 1949. gadam LELB un EELK vēsturē izdalāms padomju periodā kā baznīcas un valsts attiecību attīstības laiks. Padomju Savienība īstenoja agresīvu sovetizāciju abās minētajās ev.-lut. baznīcās, pārejas posms ${ }^{20}$ no 1944. līdz 1945. gadam bija beidzies, Reliǵijas kultu lietu padome (RKLP) Latvijā un Igaunijā ar pilnu jaudu sāka īstenot sistemātisku baznīcas dzīves pielāgošanu sociālisma-komunisma sabiedrības apstākḷiem.

Šìs pārmaiņas sākotnēji tika realizētas ar represijām, iebaidī̌anu, atbrīvošanos no nevēlamiem cilvēkiem, paralēli tam tika īstenotas arī institucionālas pārmaiņas LELB un EELK augstākajos līmeņos - Virsvaldē jeb konsistorijā un ev.-lut. dzīvi regulējošajā Baznīcas satversmē (turpmāk - Satversme). Par lielajām pārmaiņām jaunajās PSR valstīs bija atbildīga RKLP un tās pilnvarotie. Latvijā un Igaunijā no 1944. gada līdz 1965. gadam darbojās divi pilnvarotie, kas bija atbildīgi par religiskām lietām, - PSRS Ministru Padomes Reliǵijas kultu lietu padomes pilnvarotais Latvijā/lgaunijā un PSRS Ministru Padomes Krievijas pareizticīgo baznīcas lietu padomes pilnvarotais LPSR/IPSR.

16 Latvijas Nacionālais Arhīvs ( LVA), 1419. f., 1448. f.

17 Eesti Ajalugu Arhiiv, 3148 f., 1. apr.

18 ERA, R-1989. f.

19 Eesti evangeelse luterliku kiriku konsistooriumi arhiiv (EELKKA).

20 Latvijā un Igaunijā Sarkanā armija neienāca vienlaicīgi, piemēram, Latgale tika ieñemta 1944. gada jūlijā, Igaunijā vācu karaspēks atkāpās 1944. gadā, Kurzemes katls pastāvēja līdz pat 1945. gada pavasarim. Tādējādi padomju varas institūcijas Latvijā un Igaunijā ienāca dažādos laikos. 
Tas, ka pareizticīgajai baznīcai bija savs pilnvarotais, kurš atbildēja Maskavai tieši, liecina par padomju varas diferencēto pieeju reliǵijas jautājumam Baltijas reǵionā. Šāda pieeja varētu būt skaidrojama ar vairākiem faktoriem - pirmkārt, Padomju Savienībā Krievijas pareizticīgo baznīca un Maskavas metropolija tika izmantotas padomju propagandai jau no Otrā pasaules kara sākuma, otrkārt, padomju varai bija haotiska pieredze ar dažādām konfesijām un ticības dzīvi Baltijā pirmajā padomju okupācijā, ${ }^{21}$ treškārt, katolu un luterāņu baznīcas automātiski tika uzskatītas par reakcionārām, jo sadarbojās ar nacisma režīmu, un tāpēc bija problemātiskas un nespēja iekḷauties pareizticīgās baznīcas kolaboracionisma vai eventuālā ateisma kategorijā.

Pilnvaroto uzdevums jau no pašām pirmajām darba dienām bija saskaņots ar 1945. gadā izdotu instrukciju, to galvenie mērķi bija "informēt valdību par religisiskiem kultiem, to stāvokli un darbību republikā, uzraudzīt pareizu padomju normatīvo aktu izpildi, kas attiecas uz apziņas brīvību izpildi; veikt [..] baznīcu, garīdznieku uzskaiti un reǵistrāciju"22. Ši instrukcija bija slepena un domāta tikai dienesta lietošanai, tāpēc pilnvarotajiem sarunās ar kultu kalpotājiem bija aizliegts uz to atsaukties. Visa dokumentācija, kuru izstrādāja RKLP saskaņā ar šo instrukciju bija ierobežotas pieejamības. Tas dažkārt noveda pie tā, ka RKLP pilnvarotajam pašam bija jāaizpilda visa dokumentācija, jāsazinās ar Maskavu utt., jo informāciju nedrīkstēja nodot tālāk padomes zemāka līmeņa darbiniekiem. Šāda slodze pirmajos pēckara gados gan radijja problēmas uzdevumi netika līdz galam izpildīti un Maskava kritizēja sovetizācijas lēno gaitu -, gan arī dažādas komiskas situācijas, kurās vainojami igauņu un latviešu padomju darbinieki, kas netī̌ām vai tīšām kavējuši pilnvaroto katra ceturkšņa atskaišu nodošanu un nebija pārliecināti par atskaišu un ziņojuma satura precizitāti. Pilnvarotajiem ierodoties LPSR, tika izvirzīti uzdevumi, kas ticīgajiem jaunajās padomju valstīs nozīmēja likumīgu apspiešanu un nebijušu kontroli, pilnvarotajam - darbu augstas spriedzes apstākḷıs, kuros jāsadarbojas arī ar čeku, bieži vien nepārzinot tās valsts valodu, kurā ir jārealizē lielie sovetizācijas plāni.

Pirmais uzdevums - izvērtēt kultu situāciju LPSR un IPSR, to nozīmi sabiedrībā, kultu dalībnieku attieksmi pret padomju varu, novērtēt to kvantitatīvo sastāvu, konfesiju organizāciju valstī līdz Otrajam pasaules karam, kultu sadarbību ar līdzšinējām varām.

Otrais - izvērtēt kultu darbiniekus dažādos līmeņos, viņu sadarbību ar nacistu varu, attieksmi un vēlmi sadarboties ar padomju varu, iespējas kļ̣ūt par ziņotājiem.

\footnotetext{
21 NKVD komisariātam bija dots uzdevums tikt galā ar baznīcu, to reorganizējot vai likvidējot jau 1941. gada februārī, taču komunistiem nepietika cilvēkresursu un prioritātes bija atrisināt ekonomiskus jautājumus, likvidēt politiskos pretiniekus un tikt galā ar īpašumu nacionalizāciju. Jaunās varas resursu trūkuma dēl, haotiskuma, tuvojošās frontes dēl padomju varai neizdevās pilnīgi reorganizēt vai likvidēt reliğisko dzīvi.
}

22 LVA, 1448. f., 1. apr. 
Augstākajos līmeņos LELB un EELK piedzīvoja pamatīgu izmeklēšanu, izvērtējumu par derīgumu padomju varai un iespējamo aǵentu vervēšanu. ${ }^{23}$

Trešais, praktiskais uzdevums bija draudžu pārreǵistrēšana, kas ievilkās līdz pat pirmās okupācijas dekādes beigām. Draudžu reǵistrācija bija viens no LELB un EELK galvenajiem sovetizācijas instrumentiem - caur šo procesu RKLP gan spēja kontrolēt draudžu skaitu, kulta ēku skaitu, nodoklı us, kuri jāmaksā draudzēm, gan piefiksēja draudžu locekļus un kalpotājus neatkarīgi no LELB un EELK uzskaites. Reǵistrācija, no vienas puses, tika veicināta (lai piefiksētu cilvēkus vēlākajām potenciālajām represijām un iekasētu no tiem nodokļus), no otras puses, bremzēta ar visiem iespējamiem līdzekl̦iem, jo bez atḷaujas draudze strādāt nedrīkstēja un nesankcionēta pulcēšanās reliğiskos nolūkos varēja tikt uztverta kā pretpadomju darbība un kā reakcionāra pēc būtības. ${ }^{24}$ Lai atjaunotu draudzes darbību, bija nepieciešami vismaz 20 cilvēku paraksti, mācītājs vai palīgmācītājs, bija jānorāda, kurās kultu telpās kulta darbība notiks (lai var piemērot nodoklus, piefiksēt dievkalpojumu apmeklētājus, it īpaši nepilngadīgos ${ }^{25}$ ). Draudžu pārreǵistrācija tika ierobežota visdažādākajos veidos, piemēram, visiem dvacatkas $^{26}$ dalībniekiem bija jābūt no vienas administratīvās vienības, kas būtiski apgrūtināja to draudžu pārreǵistrāciju, kur draudzes locekl̦i bija no cita rajona. ${ }^{27}$ Dvacatkas savākšana īpaši sarežğìta bija dažādu jaunizveidoto rajonu un administratīvo vienību pierobežā, arī Igaunijas un Latvijas pierobežās, pilsētās un ciemos. ${ }^{28}$

23 Talonens, op. cit., $17-18$.

24 Ironiski - 40 gadus vēlāk šāda nesankcionēta pulcēšanās reliǵiskos nolūkos tiešām bija pretpadomiska un reakcionāra - tika izveidota kustība "Atdzimšana un atjaunošanās", kas radās kā alternatīva stagnācijai grimstošajā LELB.

25 Kristības un iesvētības RKLP un baznīcu attiecības saasināja jau no pirmajām okupācijas nedēlāām, jo padomju vara teorētiski aizliedza veikt svētdarbības ar nepilngadīgiem, ar reliǵiju nodarboties varēja pieauguši, pilngadīgi cilvēki, kuri izprot savu antipadomju dzīvesveidu un tā sekas. Nepilngadīgiem draudžu locekļiem arī nevarēja piemērot nodokļ̣us, jo viņi nestrādāja.

26 Dvacatka kā jēdziens parādās publikācijās, kas rakstītas gan igauņu, gan angḷu valodā, to tulkojumi šajās valodās ar laiku ir atmesti, un saglabāta ir krievu valodas versija. Autore uzskata, ka šis jēdziens ir jāievieš arī latviešu historiogrāfijā un to nav nepieciešams tulkot, tas ir pašpaskaidrojošs.

27 Sepo Zeterbergs norāda, ka, piemēram, Igaunijā jaunās rajonu robežas novilka brīvi, neņemot vērā vēsturiskos un geogrāfiskos aspektus un iznīcinot senseno apriņ̧̧⿻ dalījumu, kas savukārt grāva vietējo identitāti. Zeterbergs, S., Igaunijas vēsture (Latvijas mediji: Rīga, 2018), 377.

28 Latvijā un Igaunijā pirmajos pēckara gados tika veiktas teritoriāli administratīvās izmaiņas, vairāki apringki pat tika "ieskaitīti” citās republikās - daļa līdzšinējā Abrenes apriņķa tika "piegriezta" Krievijai, Igaunijā Petseri zemes jeb Setumā dienvidaustrumu Igaunijā arī pievienoja Krievijai. Mūsdienās zināmākā robeža, kas piedzīvoja izmaiņas, ir zeme uz austrumiem no Narvas upes, tā tika pievienota L̦eñingradas apgabalam. 
Kādi bija tie cilvēki, kas tika nosūtīti no Maskavas uz Latviju kontrolēt reliǵiju un ziņot par to? Gan uz Latviju, gan Igauniju visbiežāk tika sūtîti cilvēki, kas agrāk bija dzīvojuši šajās zemēs, vai arī revolucionāri, kas Pirmā pasaules kara laikā bija devušies uz Krieviju un nebija atgriezušies atpakals. Šiem cilvēkiem gan bija vājas dzimtās valsts zināšanas, kas apgrūtināja viņu darbu, piemēram, tāds bija pilnvarotais Voldemārs Šeškens, kas dzimis Rīgā, ilgu laiku dzīvojis Daugavpilī un pēc tam devies uz Krieviju, kur vēlāk jau PSRS darbojies VĀK (vēlāk čeka) un citos iekšējās drošības orgānos. Pilnvarotā latviešu valodas zināšanu trūkums un pārāk familiārā attieksme pret ticīgajiem Latvijā no Maskavas puses tika nosodīta. Vēlāk Šeškena darbība Latvijā no 1945. līdz 1948. gadam tika vērtēta kā neveiksmīga un to nomainīja Jūlijs Restbergs, kurš dzimis 1892. gadā Rīgā, piedalījies Pirmajā pasaules karā, bija Komunistiskās partijas biedrs kopš 1917. gada. Kopš 1919. gada strādājis VĀK un Apvienotās valsts politiskās pārvaldes orgānos, strādājis Maskavā un vēlāk nosūtīts uz Rīgu. 1960. gadā devies pensijā. ${ }^{29} \mathrm{Abiem}$ pirmajiem pilnvarotajiem, kuri kontrolēja pirmos sovetizācijas solus Latvijā, bija pieredze VĀK, un viņi nebaidijās izmantot šos sakarus un pieredzi arī reliǵijas uzraudzǐšanā Latvijā. Ar to vairāk izcēlās J. Restbergs, kura ziņojumi laikā no 1948. līdz 1960. gadam pasliktināja attiecības ar Gustavu Tūru, piemēram, katra ceturkšña atskaitēs parādījās ziņas par Gustava Tūra pašdarbību ${ }^{30}$, aroganto uzvedību ${ }^{31}$ un nesaskaņotajām vizitācijām. ${ }^{32} \mathrm{~J}$. Restberga darbība un kontrole RKLP bija svarīga no 1950. gada, kad sākās LELB iesaistī̌sanās Miera kustībā, kas nozīmēja vairāk ekumenisku kontaktu, cel̦ošanu uz ārzemēm, konfliktus ar G. Tūru un Virsvaldi šo procesu dēḷ. Pirmo pilnvaroto unikālais uzdevums līdz 50. gadu sākumam bija arī veidot attiecības ar jauno arhibīskapu un informēt par padomju nostāju daudzos jautājumos, kas skāra Virsvaldi. Attiecības bija turbulentas, jo J. Restbergs, stājoties amatā, par savu uzdevumu izvirzija novērst Šeškena nepareizās attieksmes un izpratnes par reliǵiju sekas LELB un LPSR.

No 1960. gada RKLP pilnvarotais bija Prolets Liepa, kura attiecības ar LELB arhibīskapu un Virsvaldi turpinājās J. Restberga izveidotajā politikâ3 ${ }^{33}$. Prolets Liepa Maskavai vairākkārt ziņoja par G. Tūra neaizstājamības sajūtu, ${ }^{34}$ kas 1967. gadā noveda pie procesa, kura rezultātā padomju arhibīskapu atbrīvoja no amata. LELB sovetizācijā būtiskāki bija pirmie divi RKLP pilnvarotie, kuri pārraudzīja baznīcas sākotnējo ieklauš̌anos

\footnotetext{
29 “Jūlijs Restbergs", Rīgas Balss, 4. marts (1973): 7.

30 LVA, 1448. f., 1. apr., 1. I., 53.

31 LVA, 1448. f., 1. apr., 249. l., 20-21.

32 LVA, 1448. f., 1. apr., 249. I., 19.

33 LVA, 1448. f., 1. apr., 242. l., 13.

34 LVA, 1419. f., 2. apr., 7. I., 70.
} 
Padomju Savienībā un tās antireliǵiskajā politikā. Savukārt P. Liepas uzdevums bija vairāk turpināt J. Restberga iesākto un pieskatīt pirmo padomju arhibīskapu G. Tūru.

Igaunijas RKLP pilnvarotie bija ar līdzīgu dzīves gaitu un karjeru IPSR drošības iestādēs, kas l̦āva viņiem tikt nosūtītiem uz Igauniju un kontrolēt IPSR reliǵisko dzīvi. Pirmais pilnvarotais bija Johanness Kivi, kurš, stājoties amatā, bija l̦oti aktīvs. R. Altnurme Kivi darbību analizējis un secinājis, ka Kivi darbības sākums ir bijis ražīgs, ja salīdzina ar Latvijas (V. Šeškens) un Lietuvas kolēgiem (A. Gailavičs), no IPSR RKLP 1946. gada pirmajā ceturksnī jau bija iesniegtas atskaites, kamēr pārējie darbu vēl nebija izdarījuši. ${ }^{35}$ Velāk, jau pēc 1946. gada, var novērot Kivi darbības palēnināšanos - EELK jaunās Virsvaldes izveidošanā un arhibīskapa meklēšanā. Atskaitēs Maskavai jau 1945. gadā ir redzams aizrādījums par informācijas nepietiekamību atskaitēs un pasivitāti ${ }^{36}$ politikas īstenošanā, uz aizrādījumiem Kivi atbild taisnojoties, ka atskaišu nepilnības ir saistītas ar tulkotāja darbu RKLP, nevis viņa paša pasivitāti. ${ }^{37}$ Kivi par EELK situāciju Maskavai 40. gadu beigās ziņo, ka efektīva metode, kā panākt luterāṇu garīdznieku un draudžu loceklu sadarbību ar RKLP un padomju drošības iestādēm, ir "iebaidīt, baumas par izsūtīšanu uz Sibīriju un ekonomisku, finansiālu atbildību [par būšanu dvacatkā] izplatās"38. Tātad drošības iestāžu cieša sadarbība ar RKLP bija viena no metodēm, kā sovetizēt un pārvaldīt luterāņu baznīcu un cita veida reliğisko darbību Johannesa Kivi vadībā arī Igaunijā. ${ }^{39}$ Pilnvarotais pildīja amata pienākumus līdz savai nāvei 1955. gada 2. janvārī.

Tautas konformisms vai tā neesamība nav gluži izmērāms, taču ir daudz pierādījumu, ka igauņi sovetizējās lēni un negribīgi. Lai veicinātu padomju struktūru darbu, RKLP sadarbība ar VDK bija likumsakarīga, jo luterāṇu baznīca padomju valstī tika uzskatīta par vienu no galvenajām ienaidniecēm, kas nelabvēlīgi ietekmē jauno padomju pilsoņu prātus, turpina saglabāt saiknes ar buržuāzisko Igauniju un vācu kultūras (baznīcas) saknēm. ${ }^{40}$ Lielāku iecietību bija izpelnījušās metodistu un baptistu draudzes, kuras sava mazā skaita dēl netika uzskatītas par nozīmīgām, drīzāk par savdabīgiem starpgadījumiem padomju antireliğiskajā darbībā. Izņēmums bija hernhūtieši, kas nedz RKLP,

35 Altnurme R., Eesti evangeeliumi luteriusu kirik ja noukogude riik 1944-1949, 35-36.

36 RKLP I. Poḷanska vietnieka atbilde uz Kivi atskaiti par 1945. gada I ceturksni, ERA R-1989 f., 2. apr., 3. l., 23.

37 ERA, R-1989 f., 2. apr., 3. l., 24.

38 ERA, R-1989 f., 2. apr., 8. l., 66.

39 A. Jarlert, R. Altnurme, "The Estonian Evangelical Lutheran Church and the Soviet Union after the Second World War", Kyrkohistorisk arsskrift (2004): 96. Norāda, ka J. Kivi pēc būtības rīkojas nelikumīgi daudzos procesos, piemēram, nelikumīgi aizslēdzot draudzes, kas pēc dvacatkas principa būtu drīkstējušas strādāt.

40 John Anderson, Religion, State and Politics in the Soviet Union and Successor States 1953-1993 (Cambridge: Cambridge University press, 1994), 34. 
nedz čekas simpātijas ar vairākiem dievkalpojumiem nedēlāa neizpelnījās, to ilustrē arī čekas represijas pret hernhūtiešu draudzēm Sāremā un Hījumā.

Sadarbību ar čeku veicināja tās pašas metodes, kuras bija piekoptas visā PSRS un LPSR, - iebiedēšana, represijas, uzaicinājumi uz "Pelēko māju" Tartu ${ }^{41}$ vai čekas galveno ēku Tallinā utt. 1949. gada marta deportācija vēl vairāk mainīja iedzīvotāju attieksmi pret padomju varas iestādēm, sadarbība ar čeku tika skatīta kā iespēja izdzīvot staļinisma terora laikā. Garīdzniekus, kuri piekrita kḷūt par ziņotājiem vai aǵentiem, tāpat bieži sociāli diskreditēja vai tiesāja, jo paranoiskais padomju aparāts neuzticējās tādiem, kas iepriekš bija izrādījuši negatīvu vai neitrālu attieksmi un pēkšņi izvēlas sadarboties. Piemēram, Kivi par prāvestu Hennu Untu raksta, ka "viņa pretpadomju darbība bija slēpta ar ārēju uzticību, iesaistoties padomju sociālajā dzīvē"42.

Pirmie iespaidi par Latvijas un Igaunijas baznīcām pilnvarotajiem bija, protams, negatīvi. Vieni no pirmajiem ziņojumiem, ko Maskavai par LELB sūta RKLP pilnvarotais V. Šeškens, ir tādi, ka tās faktiskais vadītājs K. Irbe ir "bezkompromisu cilvēks" un ka lìdz Kurzemes jautājuma atrisināšanai viņu varētu pieciest, bet pēc pilniggas Latvijas atbrīvošanas vajag rezerves kandidatūru [..]. ${ }^{43}$ Irbes un Šeškena attiecības noteikti neuzlaboja Irbes noliedzošā attieksme pret vajadzību ziņot RKLP par vācu noziegumiem un luterāņu apspiešanu vācu okupācijas laikā, jo Irbe tādus nevarēja atminēties ${ }^{44}$, un viņa sprediķi par mežabrāliem jeb tiem, kuri nav ar viņiem, bet ir tālu cīnoties par taisnību ${ }^{45}$, tāpēc Šeškens ziņo, ka tikai 2\% luterāņu ir uzticīgi padomju varai, un vaino Irbi iedzīvotāju pārāk lielā evañgelizācijā. ${ }^{46}$ Par EELK darbību nacistu laikā un situāciju īsi pēc Otrā pasaules kara pilnvarotais J. Kivi ziņoja, ka [igaun,u] luterāņu baznīca nekad nav meklējusi sadarbību ar sociāli un politiskām progresìvām grupām, tā vietā saistījusi sevi ar reakcionāriem spēkiem un elementiem ${ }^{47}$. Kivi sūdzējās, ka Padomju armijā tika iesaukti tikai seši igauņu mācītāji, vairāki mācītāji nacistu un padomju varas nomaiņas laikā ir atbalstījuši mežabrālus. ${ }^{48}$ Pēc tam vinsš norāda, ka Igaun,u [evangógeliski luteriskā] baznīca

\footnotetext{
41 Rīgas un Peplera ielas stūrī.

42 Goeckel, op. cit., 44.

43 Gintere, S., Zālīte, I. "leskats Latvijas evangéēliski luteriskās Baznīcas vēsturē”, Ceḷš 1(44) (1992): 98-99.

44 LVA, 1448. f., 1. apr., 239. l., 4.

45 J. Talonens, 16. pielikums. V. Šeškena ziņojums "Par Latvijas Luterāņu baznīcas arhibīskapa pienākumu pagaidu pildītāja K. IRBES pretpadomju noskaņojumu un darbību”. 1945. gada oktobrī.

46 Goeckel, op. cit., 37.

47 Goeckel, op. cit., 13. Ar reakcionāriem spēkiem Kivi saprata gan K. Petsa režīmu, gan nacistu okupāciju, kurā EELK draudzes un mācītāji ir "sadarbojušies ar varu", lai gūtu sev labumu no valdošā režīma.

48 ERA, R-1989 f., 1. apr., 4. I., 4-5.
} 
[lìdz šim] nemaz nav eksistējusi, tā drīzāk ir vācu [ev. lut.] baznīca, ar vācu uzskatiem un domām, tikai igauņu valodā ${ }^{49}$. No 1944. līdz 1946. gadam RKLP pilnvarotais Kivi un tā padotie izvērtēja visas konfesijas un reliǵiskās kustības Igaunijā, to ietekmi uz cilvēku dzīvi. Viens no galvenajiem secinājumiem bija - lai gan ev.-lut. baznīca kara laikā bija zaudējusi milzīgus cilvēkresursus un bija novājināta vadības līmenī, tai vēl joprojām bija pārāk liela ietekme uz cilvēku reliǵiozitāti un Maskava un galvenais Komunistiskās partijas galvenais ideologs A. Ždanovs nebija apmierināti ar šo situāciju.

\section{Baznīcas vadības maina - jaunie arhibīskapi Gustavs Tūrs un Jāns Kīvits}

Nākamais sovetizācijas process bija Latvijas un Igaunijas luterāņu baznīcas vadības maiņa, pilnvarotajiem bija uzdevums atrast tādas baznīcas augstākās amatpersonas, kuras bija piemērotas padomju varai. Piemērotas - ar nevainojamu vai vismaz ciešamu reputāciju līdzšinējā darbībā, augstu konformisma pakāpi un vēlmi (dažādu motīvu vadīti) sadarboties ar padomju varu un RKLP. Izvēles iespējas gan bija ierobežotas, un RKLP nācās sadarboties ar tiem, kuri bija pieejami un pret kuriem vērstās "pierunāšanas metodes" strādāja. Autore uzskata, ka liela nozīme sovetizācijā bija tieši arhibīskapiem, jo vinu vadībā un sadarbībā gan ar RKLP, gan baznīcas amatpersonām un luterāṇiem baznīcas piedzīvoja milzīgas pārmaiņas, jaunā baznīcas vadība nāca no baznīcas iekšienes, nevis tika izvēlēta laicīga persona. Tādējādi padomju varai bija attaisnojums izmaiņām baznīcas formā un būtībā - pie vadības taču ir viņi paši - latviešu un igauņu mācītāji. Latvijā pirmais padomju ev.-lut. baznīcas arhibīskaps bija Gustavs Tūrs, Igaunijā - Jāns Kīvits seniors. ${ }^{50}$

Abu arhibīskapu ceḷš uz jauno amatu pēc valstu okupācijas bija līdzīgs, taču G. Tūra vervēšana un iepriekšējās Virsvaldes nomaiņa 1946. gadā noderēja kā piemērs Igaunijas notikumiem 1948. gadā. Izmainu nepieciešamību LELB Virsvaldē noteica PSRS religíjas politika kā tāda, taču V. Šeškena pieredze ar Kārli Irbi un citiem pretpadomju elementiem lika risināt šo jautājumu pēc iespējas ātrāk. Jaunā arhibīskapa meklējumi sākās jau 1945. gadā, kad V. Šeškena komunikācija ar K. Irbiji un citiem "vecā kursa" Virsvaldes locekliem bija cietusi neveiksmi. ${ }^{52}$ Šeškena ieteikums K. Irbem brīvprātīgi atteikties no arhibīskapa vietas izpildītāja 1945. gada pavasarī varētu paglābt Irbi no

49 Goeckel, op. cit., 13.

50 Jāns Kīvits (1906-1971) bieži tiek minēts kā Jāns Kīvits seniors, jo viṇa dēls Jāns Kīvits jaunākais (1940-2005) arī kḷuva par mācītāju, vēlāk arī par EELK arhibīskapu (1994-2005). Šeit un turpmāk ir runa par Jānu Kīvitu senioru.

51 LVA, 1448. f., 1. apr., 239. I., 52-53.

52 LVA, 1448. f., 1. apr., 241. l., 3-5. 
vēlākajām represijām, taču K. Irbe atteicās atstāt amatu, cerot un principiāli gaidot Teodora Grīnberga un Edgara Berga atgriešanos. ${ }^{53}$ RKLP pilnvarotais zinoja Maskavai par nepieciešamību mainīt baznīcas vadību, un šāda iniciatīva tika apstiprināta. ${ }^{54}$ 1945. gada beigas un 1946. gada sākums pilnvarotajam V. Šeškenam bija darba un spriedzes pilns laiks. Bija pasliktinājusies situācija starp PSRS un pārējo pasauli, bija nepieciešams apstiprināt to, ka Latvijā un PSRS nenotiek nekāda reliǵijas apspiešana, ar K. Irbi šāda prezentācija nebija iespējama, viņš atklāti iestājās pret padomju varu un tās attieksmi pret baznīcu. Bija nepieciešams gatavot apsūdzības pret K. Irbi, A. Siļ̧̧i un P. Rozenbergu un vienlaikus meklēt jaunu, padomju varai lojālāku un vieglāk vadāmu arhibīskapa vietas izpildītāju, kurš nekonfliktētu ar RKLP un veicinātu, nevis bremzētu sovetizāciju. Tika meklēti starpkaru perioda mācītāji, kuri nebija sevi kompromitējuši nacistu laikā, tādi, kuriem bija pieredze un saistība ar Virsvaldes darbību. Šāds kandidāts atradās - Gustavs Tūrs ${ }^{55}$ bija vienīgais Latvijā palikušais baznīcas Virsvaldes plenārsēdes loceklis ${ }^{56}$, kas bija ievēlēts 1928. gada un 1931. gada sinodē. 1946. gada februārī arestēja K. Irbi un pārējos Virsvaldes locekḷus, pret kuriem tika vērstas apsūdzības, un G. Tūra "politiskā" karjera varēja sākties. ${ }^{57}$

Mācītājs Gustavs Tūrs ${ }^{58}$ dzimis 1890. gada 24. maijā Praulienas pagastā astoņu bērnu goimenē. Mācījies ǵimnāzijās Rīgā un Pēterburgā, 1910. gadā uzsācis studijas Tartu Universitātē jurisprudences nodaļā, vēlāk sācis studēt teologiiju. ${ }^{59}$ 1918. gadā mācības pārtraucis, 1920. gadā ordinēts par mācītāju. Pirmā stabilā kalpošanas vieta bijusi Bauskas evangéēliski luteriskās baznīcas latviešu draudze, paralēli strādājis arī par ticības mācības skolotāju Bauskas giimnāzijā un pildījis 13. Bauskas aizsargu pulka mācītāja pienākumus. ${ }^{60} \mathrm{~J}$. Talonens norāda, ka nepabeigto mācību dēḷ Tūra teologis-

53 LVA, 1448. f., 1. apr., 241. l., 3-5.

54 J. Talonens, 16. pielikums. V. Šeškena ziņojums "Par Latvijas Luterāṇu baznīcas arhibīskapa pienākumu pagaidu pildītāja K. Irbes pretpadomju noskaņojumu un darbỉbu”. 1945. gada oktobrī.

55 LVA, 1448. f., 1. apr., 241. 1., 3.

56 Rozentāls, op. cit., 99-101.

57 LVA, 1448. f., 1. apr., 241. l., 3-5. V. Šeškens ziņo, ka Gustavs Tūrs jau pošas ar visu savu sadzīvi no Alūksnes, lai pildītu arhibīskapa vietas izpildītāja pienākumus Rīgā.

58 Autore lieto uzvārda versiju "Tūrs", saglabājot iepriekšējā historiogrāfijā lietoto tradīciju. A. Urtāns norāda, ka Tūram personu apliecinošos dokumentos lietoti abi uzvārdi Turss-Tūrs, taču autore par to pārliecināties šobrīd nevar. Tāpat "Turss" tiek bieži lietots starpkaru un trimdas periodikā, atsakoties lietot padomju laikā pieñemto formu "Tūrs". Būtību tas nemaina, taču ir svarīgi saprast, kāpēc dažādos avotos parādās dažādas uzvārda versijas.

59 Aigars Urtāns, "Mācītājs Gustavs Tūrs bija pretrunīga personība”, Bauskas Dzīve, 17. februāris (1999): 8. Turpinājums, 24. februāris (1999): 8.

60 Talonens, op. cit., 62. 
kās zināšanas esot bijušas nepilnīgas. ${ }^{61}$ Ģimnāzijas laikā, kad Tūrs pildīja skolmeistara u. c. pienākumus, viņš aizrāvies arī ar Austrumu reliǵijām, dievturību. Politiskajā piederībā esot bijis nacionāli noskaņots, pēc K. Ulmaņa īstenotā apvērsuma Tūra sprediķos bijuši aizlūgumi par Vadoni un citiem ievērojamiem valsts vadītājiem. Vecākie Bauskas iedzīvotāji G. Tūru atceras kā smalku, ar manierēm apveltìtu cilvēku, kas vienmēr labi gērbies un kam paticis ceḷot un baudīt dzīvi. ${ }^{62}$ Tas, iespējams, novedis G. Tūru pie alkatības, un ap 30. gadu vidu viņš pieprasijis par savu darbu neadekvātu ziedojumu apjomu, 1939. gadā LELB Virsvaldē nonākušas sūdzības par vinu un sākta izmeklēšana. Izmeklēšanu par piemērotību amatam pārtrauca 1940. gada okupācija, tāpēc nav skaidrs, vai sūdzības par Tūra alkatību ir patiesas. ${ }^{63}$

Analizējot Gustava Tūra biogrāfiju līdz periodam, kad viņš sāka pildīt arhibīskapa pienākumus, var novērot oportūnismu, kuru ar lielu prieku Tūram pārmeta trimdas garīdzniecība un sabiedrība ${ }^{64}$, taču arī LPSR bijušās draudzes un darbavietas gluži mierā ar viņa spēju mainīt politiskos uzskatus nebija. Novērojumi par vēlēšanos dzīvot grezni, neprognozējama, pat ekscentriska rīcība tiks pārmesta vēlāk arī no padomju puses. ${ }^{65}$ Tas var liecināt par to, ka Tūra uzvedība un raksturs tiešām tādi arī bija. Historiogrāfijā līdz šim G. Tūrs vērtēts pēc viņa darbiem un pēc tā, kā viņš sadarbojies ar padomju varu, taču arī vina uzvedība starpkaru periodā, pirmajā padomju okupācijā un vācu laikā liecina par kolaboracionismu un tiekšanos atrasties varas pozīcijās. Roberts Feldmanis, cienot G. Tūra darīto viṇa labā, par "sarkano arhibīskapu" izteicies vislaipnāk, minot, ka arhibīskaps vienmēr bijis laipns, inteligents un rūpējies par savām draudzēm. ${ }^{66}$ Sadarbība ar čeku nekur nav pierādīta, tomēr ir pilnīgi skaidrs, ka G. Tūrs sadarbojās ar padomju varu un čeku, citādi 1946. gada karjeras izmaiṇas nebūtu iespējamas.

1944. gadā, vācu karaspēkam atkāpjoties, Igauniju pameta arhibīskaps Johans Keps un lielākā daļa Virsvaldes. Par arhibīskapa v. i. kḷıua Antons Elarts, taču 1944. gada novembrī padomju drošības iestādes viņu apcietināja. Par arhibīskapa pienākumu izpildītāju tika iecelts Augusts Pāns, kurš, darbojoties baznīcas organizatoriskajā

61 "Mācītājs Gustavs Tūrs bija pretrunīga personība", Bauskas Dzīve, 17. februāris (1999): 8. Turpinājums, 24. februāris (1999): 8.

62 "Kas ir Gustavs Turss un kāpēc padomju vara viṇu izmanto saviem nolūkiem”, Laiks, 31 jūlijs (1957): 5.

63 Ibid.

64 “Gustavs Turss ievēlēts par "archibīskapu”", Latviešu zinas: Latvian news, 8. aprīlis (1948): 2; "Divi brāḷi - Tursi. No atmiṇu krājuma "Dzintara krastā”", Latvija Amerikā, 18. aprīlis (1959): 6.

65 1967. gadā tālaika RKLP pilnvarotais Prolets Liepa ziṇoja, ka "G. Tūrs kḷuvis vis viegli aizkaitināms un neiecietīgs, sākusi izpausties lielummānija un domas par savu neaizvietojamību". LVA, 1419. f., 2. apr., 7. l., 70.

66 Roberts Feldmanis, Dr. theol. Gustavs Turss Latvijas evaṇ̃éliski luteriskās Baznīcas Archibīskaps, http://www.robertsfeldmanis.lv/lv/?ct=teologiski_raksti_2\&\&fu=a\&id=7 (skatīts 14.05.2021.) 
komitejā, pārñēma baznīcas un Virsvaldes vadību. 1945. gada janvārī tika ievēlēta pagaidu Virsvalde un pagaidu arhibīskaps ${ }^{67}$ A. Pāns savu amatu pildijja līdz 1948. gadam. 1948. gadā RKLP pilnvarotais, sadarbojoties ar Maskavu, nolēma, ka ir nepieciešams jauns arhibīskapa vietas izpildītājs, - pēc konfliktiem ar Pānu par tādiem procesiem kā iesvētišsana un īpašumu nacionalizācija. Kivi ziņoja, ka pašreizējā Virsvalde ar arhibīskapu "tikai izsakās patriotiskos toṇos, [..], neizmanto vārdus "padomju vara", "padomju valsts", tā vietā lieto vara un valsts" ${ }^{68}$. Tika meklēti jauni iespējamie arhibīskapi, kā piemērots kandidāts atradās Viru apriņķa prāvests, kuru ļoti ātri pārvietoja uz Tallinu, lai realizētu jaunās Virsvaldes un arhibīskapa nomaiñu. ${ }^{69}$

Mācītājs Jāns Kīvits (Jaan Kiivit) seniors dzimis Tuhalānē, Viljandi apriņkịī, 1906. gadā dzirnavnieku gimenē. Pēc mācībām Viljandi gimnāzijā Kīvits devies studēt teoloğiju Tartu Universitātē. Ģimenes locekļi par Kīvita ambīcijām izteikuši kritiku, jo vinš̌ nemācējis ne izteiksmīgi runāt, ne dziedāt. Studiju gaitās Tartu Universitātē esot bijis jautrs un aktīvs students ${ }^{70}$, bet nepievērsis lielu uzmanību studijām. Ģimnāzijas un studiju laikā aizrāvies ar kreisajām idejām, lasījis Ničci, Šopenhaueru un stoiḳus, pievērsies Bībeles studijām, lai gūtu atbildes, kuras interesē pašam par savu dzīvi. ${ }^{71}$ No 1925 . lĩdz 1932. gadam turpinājis mācības, 1933. gadā arhibīskaps Johans Kuks ordinējis Kīvitu par mācītāju. Kalpošanu uzsācis Jehvi draudzē par vikāru, vēlāk pārcelts uz Emmastes draudzi Hījumā. No 1933. līdz 1948. gadam kalpojis Viru-Jāgupi draudzē, 1940. gadā kḷuvis par prāvesta vietas izpildītāju Viru apriņkīi, no 1940. līdz 1948. gadam bijis Viru apriņ̧̧a prāvests. ${ }^{72}$ Jāna Kīvita kalpošana dažādās draudzēs un EELK amatu ieñemšana starpkaru periodā, kā arī Tartu Universitātes absolvēšana - tas vēlāk, arhibīskapa laikā, padarijja Kīvitu par uzticamāku personu arī trimdas igauņiem, kur, kā norāda prof. Elmārs Salumā, "vinšs bija ļoti populārs un pārspēja citus igauņu teologus"”3. Jānam Kīvitam, atšķirībā no Gustava Tūra, izveidojās ǵimene, piedzima pieci bērni, dzīve netika ierauta nemitīgos skandālos, biogrāfijās nav aprakstīti mēgeinājumi bēgt no Igaunijas kara laikā..$^{74}$

67 EELKAA, 1.1. 100. 32-39. 1946. gada 30. janvāra Virsvaldes protokols, kurā tiek apskatīti notikumi no 1944. līdz 1946. gadam, 1946. gada plāns EELK, protokolu noslēdz A. Pāns, F. Jirgensons.

68 ERA, R-1989 f., 1. apr., 4. l., 5; Goeckel, op. cit., 44.

69 Goeckel, op. cit., 33.

70 Vairāku studentu biedrības biedrs - Akadeemilisse Usuteadlaste Seltsi (Akadēmiskā teologu biedrība) un Akadeemilisse Filosoofia Seltsi (Akadēmiskā filozofijas biedrība).

71 https://et.info-about.info/22175/1/jaan-kiivit-seenior.html

72 Jaan Kiiivit, https://www.geni.com/people/Jaan-Kiivit/6000000005041714250

73 Goeckel, op. cit., 33.

74 ERA, R-1989 f., 2 apr., 3. I., 60. 
1948. gadā RKLP aktīvas darbības rezultātā J. Kīvits pārcelts uz Tallinas apriņ̧̧i, kur kalpojis par Tallinas apriņķa prāvestu, līdz 1949. gada 2. februārī ievēlēts par arhibīskapu. Pirms kḷū̌šnas par arhibīskapu J. Kīvits ir komunicējis ar arhibīskapu G. Tūru par to, kā vadīt baznīcu, abu attiecības bija orientētas uz sadarbību. Piemēram, 1949. gada EELK Virsvaldes 23.-24. oktobra sēdēe ${ }^{75}$ piedalijās arī G. Tūrs un G. Šaurums, kuri apsveica EELK un jauno arhibīskapu, vēlot daudz darba sociālisma garā. ${ }^{76}$ Sēdē piedalijjās arī RKLP pilnvarotais J. Kivi. 1948. gadā, čekas savervēts, darbojies ar segvārdu Juri I. ${ }^{77}$ Historiogrāfijā autore nav atradusi J. Kīvita sadarbības ar čeku vērtējumu, viña sadarbība drīzāk tiek raksturota vai pieminēta pašsaprotamā sadarbībā ar padomju varu, ko paǵēēeja viña ieñemamais amats un laikmeta realitāte.

1946. gada 21. februārī tika apcietināti iepriekšējie Virsvaldes loceklị K. Irbe, A. Siļ̧̧⿻ un P. Rozenbergs, par galveno apsūdzību uzrādot nevēlēšanos sadarboties ar padomju varu, esot ev.-lut. baznīcas Virsvaldēe. ${ }^{78} \mathrm{~K}$. Irbes ilgstošie konflikti ar V. Šeškenu, ${ }^{79} \mathrm{~A}$. Silļ̧es neveiksmīgā čekas aǵenta karjera ${ }^{80}$ un prāvesta P. Rozenberga sūdzības RKLP pilnvarotajam par savu kolēgu apcietināšanu rezultējās ar viņu apcietināšanu, apsūdzot tos pretpadomju noskaņojumā. ${ }^{81}$ "Vecais kurss" bija kapitulējis, un divu gadu laikā RKLP darbība bija panākusi pirmskara amatpersonu diskreditēšanu, iebiedēšanu, savervēšanu un arestēšanu.

Pēc Virsvaldes locekḷu apcietināšanas vienīgie LELB Virsvaldes locekḷi bija palikuši prāvests A. Virbulis ${ }^{82}$ un kasieris K. Šlosbergs. 1946. gada 8. martā Virsvaldes sēdē Rīgā,

\footnotetext{
75 EELKKA, 1.1.101., 1.- 41.

76 EELKKA, 1.1.101., 3.

77 Geockel, op. cit., 53

78 Andris Bergmanis, "Latvijas evangéēliski luteriskā baznīca no 1944. gada līdz 1968. gadam” // Teoloǵija: teorija un prakse. Mūsdienu latviešu teologu raksti, I. (Rīga: Zvaigzne ABC, 2005), 312.

79 Piemēram, K. Irbe cel̦oja pa Latviju un apmeklēja draudzes bez saskaņošanas ar RKLP pilnvaroto. LVA, 1448. f., 1. apr., 239. l., 52-53. Konflikti ar V. Šeškenu par bērnu liturǵiju svētdienās, kurā K. Irbe esot izteicies "Nu tad mūs vajag iesēdināt! Jo izmainīt kārtību, kas ir no seniem laikiem, nevar!"; Bergmanis, op. cit., 310; LVA, 1448. f., 1. apr., 239. I., 55.
}

80 LVA, 1448. f., 1. apr., 239. l., 4.

81 1946. gada 25. jūnijā bijušie Baznīcas vadītāji tika tiesāti, Irbe un Siļֵ̧e sañēma 10 gadus cietumsoda spaidu nometnē, Rozenbergs - piecus. Ir izskanējuši apgalvojumi, ka G. Tūrs mēginājis mīkstināt vadītāju saņemtos sodus, taču arhīvā tas neatklājas, arī trimdas prese to neapstiprina. Irbi nosūtija uz Karagandu, Silķi uz Vorkutu. Ëriks Mesters, Latvijas evanǵgéliski luteriskās baznīcas vēsture (1944-1990) (Rīga: Klints, 2005), 17-18.

82 Par A. Virbul̦a nozīmīgumu līdz šim historiogrāfijā rakstīts maz, taču jāatzīmē, ka G. Tūra kandidatūru par nākamo arhibīskapu ietekmēja A. Virbuļa saistība ar G. Tūru - abi bijuši studentu korporācijas Lettonia biedri un seni draugi. A. Virbulis sadarbojās ar V. Šeškenu nākamā arhibīskapa izvēlē. Talonens, op. cit., 59-60; Album Lettonorum 1870-1930 (Rīga: Lettonia, 1930), 92, 99. 
piedaloties Virsvaldes loceklịem, par vēl vienu locekli tika ievēlēts mācītājs Gustavs Tūrs. Virsvalde ievēlēja Tūru par arhibīskapa vietas izpildītāju, Virbuli - par Virsvaldes priekšsēdētāja vietnieku, Šlosbergu - par Virsvaldes generālsekretāru..$^{83}$ 1946. gada jūnijā pēc A. Virbula nāves viña amatu ieñēma G. Šaurums, Revīzijas komisijā ievēlēts P. Kleperis. Pēc visām izmaiņām LELB vadībā bija Tūrs, Kauliņš, Kleperis un Šaurums, visu izmaiņu veikšanā klāt bija RKLP pilnvarotais V. Šeškens, kurš apmierināti ziñoja Maskavai, ka LELB vadība ir nomainīta. ${ }^{84}$

No 1946. gada marta notika vairāki procesi: 1) Gustava Tūra ievēlēšana arhibīskapa v. i. amatā; 2) LELB ekonomiskā stāvokḷa apzināšana un mēgeinājumi to uzlabot; 3) gatavošanās LELB Satversmes labošanai un Ģenerālajai sinodei 1948. gada martā.

Gustava Tūra pirmie soḷi arhibīskapa amatā bija LELB organizatorisku jautājumu atrisināšana - baznīcas vadības iecelšana, dievnamu un kapu apsaimniekošana, draudžu pārregistrācijas process kopā ar RKLP. Komunikācija ar luterāṇiem visā Latvijā G. Tūram sākās ar aicinājumu ziedot kara bāreņiem, ${ }^{85}$ ar Padomju Latvijas luterāņu apsveikšanu Lieldienās ar apkārtrakstu, kurā jaunais arhibīskaps padomju garā uzrunāja luterāñus un norādỉja uz Otrā pasaules kara postu un vāciešu noziegumiem, vairākām LPSR esošām sociālajām problēmām - pārlieku alkohola lietošanu, darba roku trūkumu u.c. ${ }^{86}$

Tomēr galvenais uzdevums ev.-lut. baznīcas sovetizācijā šajā laika posmā bija Latvijas PSR evanģêeliski luteriskās baznīcas Satversmes izveidošana. Jau 1947. gadā arhibīskapa v. i. un baznīcas vadība sāka gatavoties Ģenerālajai sinodei, kurā G. Tūrs kḷ̣ūtu par arhibīskapu ar visām tā pilnvarām un pienākumiem. G. Tūra ievēlēšana Ģenerālajā sinodē par arhibīskapu pabeigtu pāreju no starpkaru perioda LELB ar T. Grīnbergu uz padomju LELB ar G. Tūru kā baznīcas galvu. ${ }^{87}$ Jaunpien̦emtā LELB Satversme pēc būtības ir juridiski jauns dokuments, kā norāda L. Rozentāls, jaunajai Satversmei ir tikai $1 / 3$ strukturālā un $1 / 5$ saturiskā kontinuitāte ar 1928. gada Satversmi. ${ }^{88}$ Analizējot jauno LELB Satversmi, Rozentāls norāda, ka tā ir līdzīga 1929. gada Nolikumam par Krievijas pareizticīgās baznīcas pārvaldi, tādējādi neizbēgami LELB tuvinot luterānu baznīcu padomju valsts pārvaldes modelim..$^{89}$ PSRS akcepts, V. Šeškena "gādība" sinodēs un

\footnotetext{
83 Talonens, op. cit., 62.

84 LVA, 1448. f., 1. apr., 242. I., 7-8.

85 LVA, 1419. f., 2. apr., 7. l., 78.

86 Talonens, op. cit., 65.

87 Lìdz šim par Gustava Tūra kā arhibīskapa pozīcijas izpildītāju izteica šaubas trimdas garīdzniecība, jo Tūrs bija nonācis amatā bez demokrātiskas sinodes un sukcesijas. Tas uztrauca arī pašu G. Tūru ap 1948. gadu. Jautājumus par G. Tūra darbību uzdeva arī viesi no Lielbritānijas 1946. gadā. Bergmanis, op. cit., 317.

88 Rozentāls, op. cit., 105.

89 LVA, 1448. f., 1. apr., 185. l., 133-136; Rozentāls, op. cit., 202.
} 
LELB jauno "kadru atlase" norāda uz to, ka ar 1948. gada Satversmes izmaiņām LELB bija kḷuvusi par LPSR "valsts baznīcu", kur valsts pārvaldes politika un LELB funkcija saplūda. 1947.-1948. gada LELB Virsvaldes nomainas procesu un arhibīskapa Tūra ievēlēšanu autore pētijusi savā bakalaura darbāa", secinot, ka "Gustavam Tūram pēc pilntiesīgas kḷušsanas par arhibīskapu tika dotas tādas tiesības un iespējas ietekmēt luterāņu baznīcu, kādas arhibīskapiem līdz šim nebija iespējamas"'1. Virsvaldes loma pēc 1948. gada Satversmes pieņemšanas bija tik loti mazināta, ka sinodes vairs nebija nepieciešams sasaukt reizi trīs gados kā līdz šim. Vēl vairāk - jau pēc pāris gadiem G. Tūram radīsies domas, ka Satversmi vajag korigêèt vēl vairāk, baznīcas pārvaldes grožus koncentrējot arhibīskapa rokās.

Igaunijas Ev.-lut. baznīcas sovetizācija baznīcas vadībā notika vēlāk nekā LELB, taču process bija gaužām līdzīgs, par piemēru ņemot Latviju. Divas atškiirības, kuras vērts uzsvērt EELK vadības nomaiņā, ir 1) Augusta Pāna personība un arhibīskapa vietas izpildìtāja darbs no 1944. līdz 1948. gadam, 2) piemēra ņemšana no Latvijas un komunikācija abu ev.-lut. baznīcu starpā baznīcas vadības nomaiņas procesā.

1944.-1946. gadā EELK baznīcas vadība centās sadarboties ar RKLP pilnvaroto savu interešu īstenošanai, taču, kā aprakstījis R. Altnurme, gan EELK vadības attieksme ir bijusi noliedzoša pret varu, gan RKLP pilnvarotais ar savām tiesībām ierobežot baznīcu darbību Igaunijā tai licis dažādus birokrātiskus šķēršlus. ${ }^{92}$ Piemēram, ir pieprasījis izstrādāt nākamā gada plānu un to ievērot, dziḷāk paskaidrot jebkurus baznīcas vadības sanākšanas iemeslus u. c. Šãds "gada plāna" svarīgums LELB komunikācijā ar V. Šeškenu gandrīz vispār neparādās, V. Šeškens ir informēts par LELB plāniem, vismaz spriežot pēc arhīva materiāliem, pat bez "gada plāna" pieejamības, pat ja tāds bija izstrādāts. Piemēram, 1946. gada 30. janvāra EELK Virsvaldes sēdē viens no dienas kārtības punktiem ir "iepriekš uzsāktie jautājumi" no 1945. gada, kas būtu jāturpina 1946. gadā. ${ }^{93}$

Šajā aspektā ir svarīgi iezīmēt A. Pāna lomu EELK sovetizācijā šajā laikā. A. Pāns kļuva par arhibīskapa v. i. 1944. gadā ar padomju varas akceptu, taču pēc šì notikuma sadarbošanās ar RKLP acīmredzami nav bijusi veiksmīga, jo no 1946. gada A. Pāna ietekme EELK jautājumos kḹust arvien mazāka, ziņojumi par Pānu - negatīvāki. To varētu skaidrot ar diviem iemesliem: 1) A. Pāns tiešām neattaisnoja RKLP priekšstatus par to, kādam ir jābūt ev.-lut. baznīcas galvai un kādā veidā ir jāīsteno padomju politika reliǵijas jautājumos; 2) pēc RKLP pilnvarotā Latvijā pieredzes ar K. Irbi un viņa atklāto

90 Diāna Grīnvalde, Latvijas evangéēliski luteriskās baznīcas arhibīskapa Gustava Türa darbība 1948.-1954. Bakalaura darbs (Rīga: LU VFF, 2018), 28-30.

91 Ibid., 32.

92 Riho Altnurme, Eesti evangeeliumi luteriusu kirik ja noukogude riik 1944-1949 (Tartu: Tartu Ulikooli, 2000), 205.

93 EELKKA, 1.1.100., 32. 
nesadarbošanos Maskava nolēma šos "starpposmus" likvidēt un, tiklīdz bija iespēja ievēlēt arhibīskapu, izvēlējās jaunus, padomju politikai un ideoloǵijai piemērotus kadrus, kuri skaidri apzinās viṇu jaunā amata "cenu". Autore piekrīt otrajam variantam, taču nav atradusi arhīvos ziņojumus uz Maskavu vai no Maskavas par to, ka Pāns būtu tikai pagaidu risinājums, ir tikai negatīvi vispārīgi raksturojumi, līdzīgi kā par K. Irbi. Par attiecību sabojāšanos liecina arī RKLP pilnvarotā asā rīcība arhibīskapa pārvēlēšanu sakarā, kur A. Pāna kandidatūra pat netika izskatīta, vēlākā apcietināšana un tiesāšana. ${ }^{94}$

EELK Virsvaldes un Satversmes nomaiņas procesa aktīvākā fāze iezīmējās pēc prāvesta J. Kīvita un LELB arhibīskapa Gustava Tūra tikšanās 1949. gadā ${ }^{95}$, kur no latviešu puses tika piedāvāts baznīcas Satversmes jaunais projekts (kas bija izstrādāts un apstiprināts RKLP pilnvarotā (Latvijā) vadībā), kuru atbalstija arī Igaunijas RKLP pilnvarotais. ${ }^{96}$ Šajās sarunās tika risināts jautājums arī par arhibīskapa iesvētišanu un sukcesijas jautājumu, jo PSRS nebija citu arhibīskapu, kas ievadītu J. Kīvitu (un patiesībā arī G. Tūru) amatā, tika apsvērta somu arhibīskapa kandidatūra, zviedru baznīcas arhibīskaps nebija piemērots, jo zviedru ev.-lut. baznīca bija uzñēmusi daudz igauņu mācītāju bēglu un tas neatbilda padomju nostājai starptautiskās attiecībās ar tagadējo PSRS zemju trimdiniekiem. ${ }^{97,98}$

1949. gada 23.-24. oktobrī Tallinas katedrālē notika Igaunijas Ev.-lut. baznīcas XIII Ģenerālā sinode. lepriekšējo mēnešu priekšdarbi bija rezultējušies ar pārliecinātu padomju varas klātbūtni sinodē. RKLP pilnvarotais sveica jauno EELK vadību un novēlēja "šodienas baznīcas padomei panākumus, lai draudžu vēstnieki pildītu savus pienākumus pēc labākās sirdsapziṇas" ${ }^{\prime 9}$. Sinodē piedalījās arī G. Šaurums un arhibīskaps G. Tūrs, kuri sveikuši jauno arhibīskapu J. Kīvitu. ${ }^{100}$ Kīvitu G. Tūrs sveic ar tekstu par brālību un kopīgu uzdevumu gan tautām, gan baznīcām. ${ }^{101}$ Kīvits Tūra draudzīgajai uzrunai atbild ar svētību Latvijas draudzēm, brālim amatā un Latvijas valstij, vēlot sadarbību starp Rīgu un Tallinu. ${ }^{102}$ J. Kīvits arī nav aizmirsis ciemošanos LEB IX G Generālajā sinodē,

\footnotetext{
94 Goeckel, op. cit., 33.

95 LVA, 1448. f., 1. apr., 185. I., 22-24.

96 Ibid., 209.

97 Altnurme, op. cit., 210.

98 Riho Altnurme savā promocijas darbā ir izmantojis Krievijas Federācijas valsts arhīvu, tādējādi viņam ir bijusi pieeja ziņojumiem, kuri citur nav publicēti. Lìdzīgi arī R. F. Gekels savā pētījumā ir apvienojis materiālus no Krievijas, Igaunijas un Latvijas arhīviem, veidojot pilnīgāku informācijas analīzi.

99 Altnurme, op. cit., 210-211.

100 EELKKA 1.1.101. EELK XIII Ģenerālās sinodes protokols, 23.-24. oktobris, 1949. gads. Tallina, 1.

101 Ibid., 3.

102 EELKKA 1.1.101. EELK XIII Ģenerālās sinodes protokols, 23.-24. oktobris, 1949. gads. Tallina, 3-4.
} 
kas notika 1948. gada martā un kur to tik laipni uzñēma LELB un Gustavs Tūrs. Pāris dienu pēc Ģenerālās sinodes Kivi ziņo I. Poḷanskim par to, kādi ir Satversmes grozījumi, un ka, "neskatoties uz baznīcas popularitāti, baznīca [Sinodes dienā] nemaz nebija tik loti apmeklēta"103.

Analizējot Igaunijas Ev.-lut. baznīcas Satversmes izmaiņas, Riho Altnurme secina, ka jaunā EELK Satversme pēc būtības ir tāda pati kā 1948. gada LELB Satversme, ar maziem izṇēmumiem nosaukumos (baznīcas padome vispārējās sinodes vietā, konsistorija baznīcas pārvaldes vietā u. c. nianses). Altnurme norāda, ka jaunais arhibīskaps īsi pirms sava amata ieņemšanas oktobra beigās izveidoja speciālu padomi, kas veica šīs izmaiņas EELK Satversmē, lai Ģenerālās sinodes otrajā dienā būtu iespējams pieņemt jauno baznīcas kārtību. Komitejā izstrādes procesā darbojies arī topošais J. Kīvits. ${ }^{104}$ Jauno Satversmi pieņēma XIII Ģenerālajā sinodē vienbalsīgi RKLP pilnvarotā J. Kivi klātbūtnē, tādējādi visiem sinodes klātesošajiem bija skaidra padomju varas nostāja un priekšstats par jauno padomju baznīcu.

Baznīcu darbība RKLP uzraudzībā bija ierobežota un piedzīvoja represijas uz katra soḷa, sējot mācītājos un draudžu loceklos bailes un neuzticību un tādējādi diskreditējot luterānisma nozīmi jaunajā padomju sabiedrībā. Par lūzumpunktu uzskatāma 1948. gada LELB jaunā Satversme un 1949. gada EELK jaunā Satversme, pēc kuras baznīcas dēvēja par LPSR vai IPSR Ev.-lut. baznīcām.

Liela nozīme Latvijas un Igaunijas luterāņu baznīcu pārveidošanā ir bijusi personībām, kas tādu vai citādu motīvu dēḷ ir izvēlējušās vadīt šīs baznīcas padomju laikā, Gustavam Tūram un Jānam Kīvitam. Abiem nonākot amatā līdzīgos apstākļos un piedzīvojot RKLP politiku, rīcība amatā un attiecības ar padomju varu līdz 1949. gadam bija salīdzinoši vienādas, izteikta atšksirība sākās no 50. gadu vidus, kad LELB un EELK saskārās ar citiem padomju luterāṇu baznīcas notikumiem un procesiem sabiedrībā un attiecībās ar trimdas luterān,iem.

Gustavs Tūrs, lai gan Latvijas historiogrāfijā bieži dēvēts par kolaboracionistu, izrādīja daudz lielāku pretošanos varai visdažādākajos veidos sava amata pilnvaru laikā, kamēr J. Kīvita vērtējums bija un ir neitrālāks, varētu teikt, pat pozitīvāks, taču tieši J. Kīvita pasivitāte noteiktos jautājumos veicinājusi Igaunijas luterāņu baznīcas iznīkšanu un sabiedrības sekularizāciju. G. Tūrs dažkārt uzvedies agresīvi un neparedzami gan no padomju varas, gan no draudžu skatpunkta, bet J. Kīvita pasivitāte pat labvēlīgākas religiijas politikas apstākl̦os neveicināja baznīcas pašsaglabāšanos, tas redzams turpmākajos arhibīskapa pienākumu pildīšanas gados līdz pat 1967. gadam.

103 Altnurme, op. cit., 213.

104 Ibid., 200-201. Apakšnodaļas nosaukums - "Jauns [Satversmes] projekts, kas balstīts uz Latvijas Baznīcas statūtiem”. 
Laika posms no 1946. gada līdz 1949. gada beigām dziḷi ietekmēja turpmāko baznīcas dzīvi, sākotnēji līdz 1967.-1968. gadam, kad abi arhibīskapi pārstāja pildīt savus arhibīskapa pienākumus, un vēlāk - līdz pat neatkarības atgūšanai Trešās atmodas laikā. Sovetizācijas būtību vieglāk saprast, analizējot arhibīskapu likteni, - tos atrada padomju vara un iecēla amatā, kad viņi bija vajadzīgi, un tos tikpat ātri "noṇēma", kad tie bija kḷuvuši pārāk neērti un laikmetam, padomju varai neizdevīgi, - 1967. gadā (J. Kīvitu) un 1968. gadā (G. Tūru). Pat ja arhibīskapiem izdevās ìstenot kādu savu ideju un paiet soli nostāk no "partijas līnijas" par labu luterāņiem Latvijā vai Igaunijā, padomju varas stingrā roka bija jūtama visās citās dzīves un ticības jomās. Sovetizācijas sākums bija izdevies - sējot neuzticību un padomju režīmam raksturīgo paranoju baznīcas iekšienē, mierinājuma un ticības stiprināšanas vietai kḷustot par represiju avotu un padomju ideologijijas ārprāta ruporu.

Nākotnes pētijumiem un citiem pētniekiem autore iesaka turpināt skatīt abu ev.lut. baznīcu vēsturi kopīgā vēsturiskā un geeogrāfiskā telpā - transnacionālās vēstures pieejā, mēginot izprast padomju varas îstenoto politiku un tās ietekmi uz baznīcām līdzīgos apstākḷos, tādējādi veidojot tiltu starp daudzajām publikācijām, kas ir par sovetizāciju igauņu un latviešu valodā, taču nesasniedz citus pētniekus un lasītājus. Šĩ tilta radīšanu, protams, veicinātu publikāciju tulkojumi anglı valodā, jauni pētijumi un Baltijas pētnieku sadarbība dažādos projektos.

\section{SUMMARY}

Sovietization of Latvian and Estonian evangelical Lutheran churches in 1946-1949

Latvia and Estonia occupied by USSR in 1944-1945 experienced drastic changes regarding religious politics. The aim of this article is to look at these changes - both internal and external and compare them through transnational approach. Lutheran evangelical churches of LSSR and ESSR went through similar process of adaption to Soviet politics, Latvian church being somewhat of a pilot project of Cult and Religion Council's strategies in Latvia and Estonia.

The paper introduces the relations of LELC and EELC with the Soviet power in different aspects within the period from 1946 to 1949, describing the roles of the CARC commissioners and the archbishops of LELC and EELC in the Sovietization processes, comparing changes of churches in the conditions of soviet socialism.

The activities of churches and archbishops under the supervision of CARC were limited, raising fears and distrust in the clergy and members of the congregations, thereby discrediting the role of Lutheranism in the newly made Soviet community. The new, CARC approved Constitutions of LELC in 1948 and EELK in 1949, could be considered a breaking point in Sovietisation of Lutheran church with archbishops Gustavs Türs and Jaan Kiivit leading the newly made Soviet Lutheran churches under the antireligious conditions. 